\title{
Craved by heart, carved next to it: Ballistic report of a souvenir bullet casing
}

\section{Acharya J', Lama G², Ranjitkar $\mathrm{M}^{2}$, Shakya $\mathrm{A}^{2}$}

${ }^{1}$ Jenash Acharya, Assistant Professor; ${ }^{2}$ Geshu Lama, ${ }^{2}$ Malshree Ranjitkar, ${ }^{2}$ Arbin Shakya, Lecturers; Department of Forensic Medicine, Legal Medicine and Toxicology, Kathmandu Medical College Public Limited, Kathmandu, Nepal.

\begin{abstract}
Background: A bullet which has been lodged in the body encapsulated by dense fibrous tissue for a long time without causing ill effects is a souvenir bullet. The bullet cartridge is divided into 3 parts: bullet, cartridge case holding bullet with gun powder and detonator at the base. Medicolegal consultation was done with Forensic Medicine Department where cartridge case acted as projectile and accidentally got embedded into the chest of the victim. In an attempt of making an ornament from the casing of bullet which was separated from bullet mechanically and gunpowder was partially removed from the bullet case. When he heated the bullet case to melt and mould, the remaining gun powder ignited with release of large amount of gas which resulted in forceful propulsion and acted as the projectile. An oval penetrating keyhole appearance injury measuring $2 \mathrm{~cm} \times 1.5 \mathrm{~cm}$ was present on left side of the chest of the victim. The projectile was found just above the $6^{\text {th }}$ rib and was confined within inter-costal muscle. Although late complications may arise from the metallic toxicity from the bullet case showing manifestations like abdominal pain, anorexia, chronic renal failure, abdominal pain, osteomyelitis, and fistula formation in bones, the projectile was left within the body as a souvenir to be intervened in case complications arise during follow-ups, as manipulating it could cause unanticipated therapeutic complications.
\end{abstract}

Key words: Bullet; Keyhole entry; Ornament; Souvenir bullet casing

DOI: https://doi.org/10.3126/jkmc.v8i1.25269

\section{INTRODUCTION}

$\mathrm{B}$ oth mortality and prognosis in cases of bodily damage sustained by any bullet or projectile is ambiguously dependent on consistency and vitality of organs injured, amount of blood loss and period between impact and its surgical extraction from the body. During its flight from the muzzle till it hits the target, velocity of the projectile decreases subsequently and the further it travels, devastations get less severe. Speed and direction of any projectile penetrating human body is disrupted by different layers of soft tissues before it hitsany boneand/ or firm and hollow visceral organs.Hence, the kinetic energy decreases and direction changes subsequently as the projectile is rendered through layers of tissues that stand-in as opposing shields. The projectile entering body either exits perforating all layers of tissues or is

Address for correspondence

Dr. Geshu Lama

Lecturer, Department of Forensic Medicine

Kathmandu Medical College Teaching Hospital,

Kathmandu, Nepal

E-mail: geshulama@gmail.com resisted by bones or soft tissues and is retained within the body. ${ }^{1}$ The risk of a retained bullet may involve a fatal consequence or potential immediate or early complication which requires surgical intervention. The bullet that remains entrenched inside a body for a long time without causing life threatening complications like infections or toxicityis loosely called $A$ Souvenir Bullet ${ }^{1,2}$. Advisably, such foreign bodies are left inside the body of victim since manipulating it could exacerbate vascular or neurological complications, sometimes even death. With time these foreign bodies cause less threat and remain isolated following encapsulation of dense and fibrous granulation tissue $e^{3-5}$.

Ammunition or cartridge of a firearm releasing bullet is mainly divided into 3 parts; the bullet, the case holding the bullet that contains gunpowder within and a detonator (primer) at the base used for ignition of the powder. On striking the detonator, it ignites the gunpowder releasing gases with expansive property thereby firing the bullet as reaction to expansion of gases within the casing. We present a report where a bullet's casing, but not bullet - acted as a projectile 
and accidentally got embedded as a souvenir into the victim's chest following an incident; a rarest of condition in the form of contribution to ballistic literature as $A$ Souvenir Bullet Casing.

\section{CASE REPORT}

\section{Clinical History}

Medico-legal consultation was sought by Emergency Department from the Department of Forensic Medicine to help analyze an alleged case of self inflicted firearm injury over the chest. On examination of the wound; an oval penetrating injury with a keyhole appearance measuring $2 \mathrm{~cm} \times 1.5 \mathrm{~cm}$ was present on left side of the chest (Figure 1b). Subsequent consultation with Department of Cardio-vascular Surgery diagnosed that; the anterio-posterior view of X-ray image of chest depicted an opaque rectangular object entrapped over the anterior aspect of chest wall just above the $6^{\text {th }}$ rib. Lateral view of the chest deduced that the projectile had not penetrated the pleural membrane and was confined within the inter-costal muscles (Figure1a). In compliance to victim's request; it was not removed but was allowed to be engraved as a souvenir. The victim well understood that the projectile would have no immediate life threatening consequences. Patient was

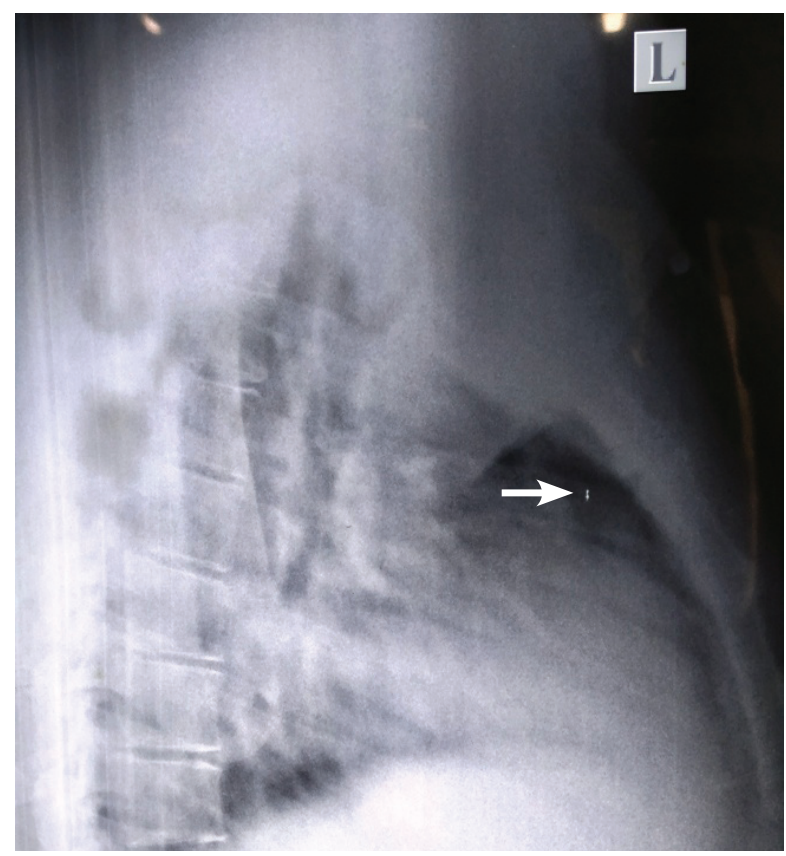

Figure 1(a) made aware about the inconsequential probability of its migration, toxicity and infection in future ${ }^{6}$.

\section{Medico-legal History}

As per the history provided by victim to Department of Forensic and Legal Medicine, he always had a craving for an ornament made of bullet casing with a mythical belief that keeping it attached to his body would cure systemic disease like hypertension and bring good luck to his family. A goldsmith by profession, he found a bullet cartridge through his friend; source of which is kept confidential by investigating officer. He tried to remove bullet from the bullet case mechanically multiple times earlier but had failed. That uneventful day he was successful in doing so. According to him, the bullet was then kept separately and blackish brown powder (gunpowder) was partially removed from the bullet case. While on a sitting position, the victim gripped the bullet casing in his right hand with forceps held at the level of his neck, with base of the bullet facing towards him and ignorantly subjected it to flame (Figure 2) with an attempt to melt and mould it into desired shape of a finger- ring. As gases from residual gunpowder expanded and escaped from the open end of the casing, the latter was propelled towards the victim and lodged in the left side of this chest.

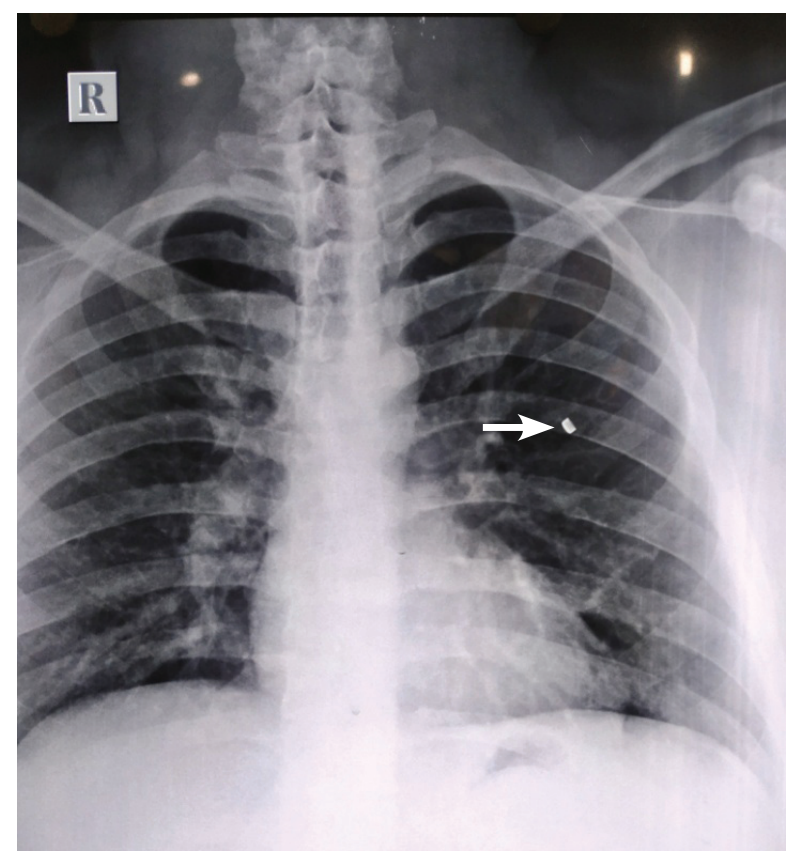

Figure 1(b)

Figure 1: X-ray images of bullet casing at the level of $6^{\text {th }}$ rib within intercostal muscles (L: Lateral, R: Anterio-Posterior) 


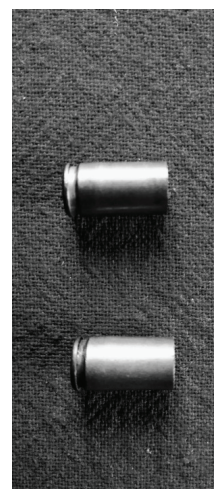

Figure $2 a$

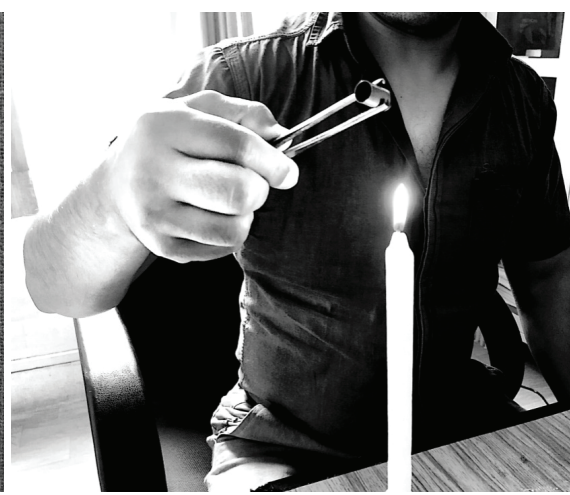

Figure $2 b$
Figure 2: a) bullet case b) Scene reconstruction by author depicting position of victim

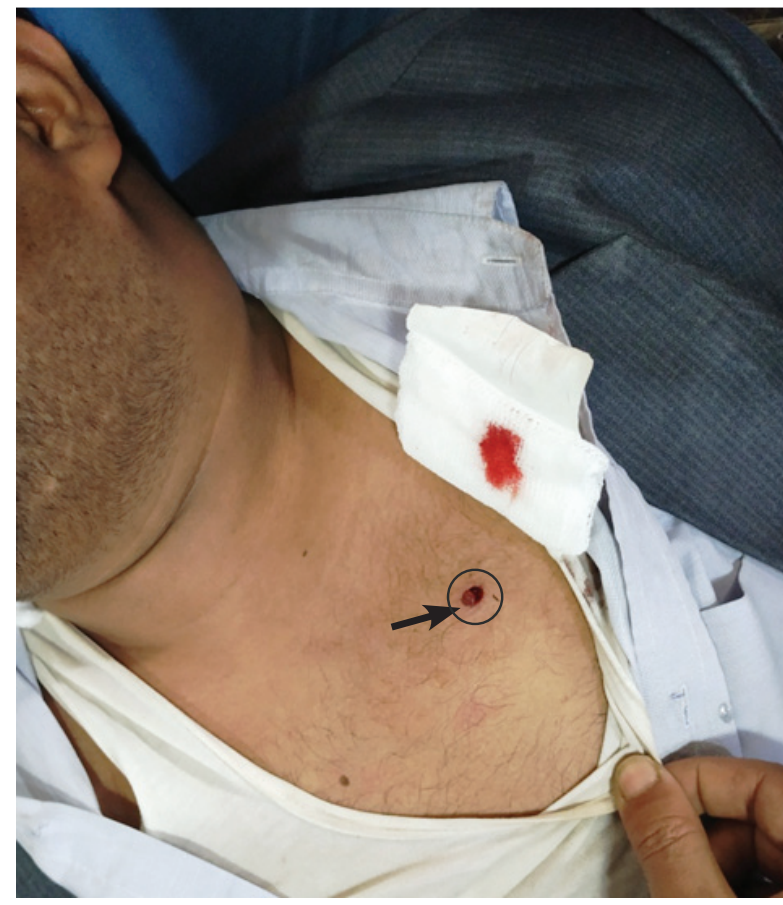

Figure 3: Encircled keyhole shaped entry wound of the projectile; arrowhead depicting tangential entry

\section{DISCUSSION}

\section{Firearms and Nepal}

Nepal Armed Violence Assessment (NAVA) that ended on 2014 issued brief report a year earlyfollowing small arms survey which estimated that civilians in Nepal have possession of 440,000 private firearms, of which only $12.5 \%$ of them were legally registered and with exception to 50-55 thousands, rest 330-385 thousands were believed to be country made guns; locally known as Katuwas. On the other hand, The Nepal Army and law enforcement agencies together possess 234, 000 small arms, nearly half the amount of what civilians possesses. The rate of illegally possessed firearms in Nepal by 2012 amounted to be 1.29 per 100 civilians $^{7}$. Nepal Arms and Ammunition Act, 2019 (1962) articulates maximum penalty for unlawful possession or storage of firearm amounting to 5 years in prison and/or fine of NPR 100, $000^{8}$.

\section{Complications of Retained Foreign body}

Gunshot wounds contaminate the tissue and site involved, which needs exploration and debridement. Following careful observation, the bullets lodged in tissues and muscles can be removed after soft tissue swelling subsides which in other case may cause fatal ascending infections. ${ }^{9}$ Lead toxicity may manifest as microcytic hypochromic anemia, chronic renal failure, abdominal pain, anorexia, neuropathy, lethargy, encephalopathy or even systemic toxicity as a result of synovial fluid dissolving lead present in articular capsule $^{9,10}$. However, in this case, the composition of the bullet case could not be ascertained through imaging technique and was planned to be removed only in case some complications occur during follow up visits.

In this particular case the victim had mechanically removed the bullet from the cartridge and some amount of gunpowder. When the cartridge case containing the primer and the remaining gun powder was heated, the thermogenic reaction released large amount of gas. The gas is in the ratio that 1 gram of black gunpowder releases about $800-1000$ cc of gas. The resultant forceful propulsion of the cartridge case held by forceps acted as the projectile.

\section{Flight of the projectile}

The keyhole appearance was suggestive of tangential penetration of a projectile at high velocity from medial to the lateral route on left side of the chest, directed above to downwards (Figure 3). The casing of the bullet had acted as an energized missile when residual gunpowder released gases with expansive property on exposure to flame.

\section{CONCLUSION}

On reconstruction of event; margin of the wound was consistent with the tangential impact of the bullet following above to downwards direction flight and matched the medico-legal history provided by the right handed victim as holding the bullet case with forceps in his right hand at the level of his neck before its flight. Although souvenir bullet is a recognized word in terminal ballistic science literatures; an attempt is made through our case to report a "souvenir bullet casing". 


\section{REFERENCES}

1. Reddy NK, Murty OP. The essentials of forensic medicine and toxicology. Jaypee Brothers Medical Publishers; 2014.

2. Karmakar RN, Mukherjee JB (2007) Forensic Medicine and Toxicology $3^{\text {rd }}$ edition Academic publishers Kolkata 396.

3. Demetriades D, Charalambides D. Gunshot wounds of the colon: role of retained bullets in sepsis. British journal of surgery. 1993 Jun;80(6):772-3. [PubMed]

4. Abe K, Beppu K, Shinohara M et al. An iatrogenic foreign body (dental bur) in the maxillary antrum: a report of two cases. Br Dent J 1992;173: 63-65.

5. Scuderi GJ, Vaccaro AR, Fitzhenry LN, Greenberg $\mathrm{S}$, Eismont F. Long-term clinical manifestations of retained bullet fragments within the intervertebral disk space. Clinical Spine Surgery. 2004 Apr 1;17(2):108-11. [PubMed]
6. Zafonte RD, Watanabe T, Mann NR. Moving bullet syndrome: a complication of penetrating head injury. Archives of physical medicine and rehabilitation. 1998 Nov 1;79(11):1469-72.[PubMed]

7. Karp A. Legacies of War in the Company of Peace: Firearms in Nepal. Nepal Armed Violence Assessment Issue Brief. 2013;2.

8. 'Prohibition to Keep the Arms and Ammunition at a Particular Fixed Place.' Arms and Ammunition Act, 2019 (1962), Act Number 45 of 2019; Section 8. Kathmandu: Nepal Law Commission. 1963, 5 February.

9. Rhee JM, Martin R. The management of retained bullets in the limbs. Injury. 1997 Jan 1;28:C23-8. [DOI]

10. Riehl JT, Sassoon A, Connolly K, Haidukewych GJ, Koval KJ. Retained bullet removal in civilian pelvis and extremity gunshot injuries: a systematic review. Clinical Orthopaedics and Related Research ${ }^{\circledR} .2013$ Dec 1;471(12):3956-60. [DOI] 
